〈연구논문(학술)〉

\author{
$\mathrm{PU} / \mathrm{MWNT}$ 발포필름의 발포 특성연구 \\ 박준형 · 박미라 · 최라희 · 김승진 ${ }^{\dagger}$ \\ 영남대학교 섬유패션학부
}

\title{
The Characteristic of PU/MWNT Foaming Film
}

\author{
Jun Hyeong Park, Mi Ra Park, La Hee Choi and Seung Jin Kim ${ }^{\dagger}$
}

School of Textiles, Yeungnam University, Gyeongsan, Korea

(Received: January 26, 2012/Revised: February 21, 2012/Accepted: March 21, 2012)

\begin{abstract}
This study surveys the characteristics of the PU/MWNT foaming film according to foaming conditions. For this purpose, firstly, 16 kinds of PU/MWNT forming films were prepared with 4 kinds of dispersion solutions (IPA/MWNT, DMF/MWNT, MEK/MWNT, and Toluene/MWNT) and 4 kinds of blowing agents (organic I, organic II, capsule, and inorganic). The electrical resistivity of these PU/MWNT foaming films according to the dispersion solutions and blowing agents were analysed and discussed with surface profile and cell morphology of measured by SEM. And secondly, 24 kinds of PU/MWNT foaming films were also prepared with 2 kinds of IPA dispersion solution contents and 3 kinds of blowing agents with variation of the blowing temperatures and film thickness. The physical properties of the PU/MWNT foaming films such as electrical resistivity (surface and volume) and triboelectricity with cell morphology were measured and discused through the quantities of IPA, blowing agent added and also physical conditions(temperature, thickness so on) for establishing optimum foaming conditions with good electrostatic dissipation.
\end{abstract}

Keywords: PU/MWNT foaming films, blowing agent, electrical resistivity, triboelectricity, MWNT dispersion solutions

\section{1. 서 론}

과학 기술의 발전과 IT산업이 발전함에 따라 전 자, 전기 및 통신관련 기기 사용이 증대되고 있으 나 제조공정중에 발생하는 정전기방전대책에 탄소 나노튜브를 사용한 많은 연구가 진행되고 있다. Das 등ㄱ은 탄소섬유/카본블랙/ethylene vinylacetate 복합 재료를 제작하여 $100 \sim 2000 \mathrm{MHz}$ 와 $8 \sim 12 \mathrm{GHz}(\mathrm{X}-\mathrm{band}$ range)대역에서 필러의 첨가량을 증가시키면서 전 자파 차폐 효율과 특성을 분석하였다. 한편 최근 탄소나노튜브를 응용한 연구가 많이 진행되고 있 으며 탄소나노튜브는 직경이 수십 nm, 종횡비 1000 이상의 나노섬유 형태로서 전기전도성이 우수하고 소량을 첨가 시 기계적 특성도 증대를 가져오는 장 점을 가지고 있다. 고분자재료가 이러한 전기적인 성질을 가짐으로써 일반적인 전기절연 특성이 아 닌 또 다른 영역의 특성 즉 $\mathrm{ESD}$ (정전방전, Electrostatic dissipation) 성능을 발휘하게 되어, 정전기 쇼 크에 의한 각종 전자제품의 오작동이나 파손을 방
지하기 위한 포장재, 자동차 전자제품의 하우징 등 으로 사용될 수 있다.

$\mathrm{CNT}$ 와 관련한 일련의 연구내용2,3)을 보면 현재 $\mathrm{CNT}$ 와 고분자 복합체인 폴리비닐리덴(Polyvinylidene), 에폭시(epoxy), 폴리프로필렌(Polypropylene), 폴리우 레탄(Polyurethane) 등 다양한 고분자들과 이루어지 고 있으며, 응용하는 고분자의 특성에 따라 인장강도, 탄성계수 등에서 다른 결과가 나타나고 있다 ${ }^{47}$.

또한 전기적 특성의 응용을 위한 복합체 제조의 경우 폴리피롤(Polypyrrole), 폴리메틸메타크릴레이 트(Poly-(methylmethacrylate), PMMA) 등 다양한 고 분자를 이용하여 전기전도성 복합체를 제조해 정전 기 방지제품 및 정전도장(electrostatic painting, 静電 塗裝), 초고용량 캐패시터(supercapacitor) 분야에 응 용하려는 연구가 진행되고 있다 ${ }^{8-11)}$.

특히 최근에 적용분야가 확대되고 있는 폴리우레 탄은 서로 다른 특성을 갖는 소프트 세그먼트와 하드 세그먼트가 공중합체로 연결되어 있어 이들 하드 및 소프트 세그먼트가 서로 상분리 됨으로서 우수한 탄

${ }^{\dagger}$ Corresponding author. Tel.: +82-53-810-3890; Fax.: +82-53-812-5702; e-mail: sjkim@ynu.ac.kr

(c)2012 The Korean Society of Dyers and Finishers 1229-0033/2012-03/79-90 
성체 특성을 나타내게 되는데 ${ }^{12,13)}$ 이와 같은 구조 에서 비롯되는 폴리우레탄이 PU/MWNT 복합필름 으로 제조하여 전자부품의 간지용으로 사용되기 위 해서는 그라운드 필름과 발포필름의 2 종류의 층으 로 제조되어 그라운드 필름층은 $\mathrm{ESD}$ 기능과 전자파 차폐기능을 반대편의 발포층은 포장재로서의 쿠션 성과 전자파 차폐성을 동시에 만족시켜야 한다. 이 러한 쿠션성이 우수한 ESD 특성은 전자부품의 간 지용 포장재로서는 기본적으로 요구되는 물성이며 이는 PU/MWNT 복합필름의 발포특성에 대한 중요 성을 보여준다.

발포체는 고체 형태의 고분자 내에 기포가 공존 하고 있는 물체를 의미한다. 우레탄은 1894년 독일 의 Wurtz와 Hoffman이 최초로 이소시아네이트와 히드록실기 화합물의 반응을 발표하면서 알려지게 되었고, 공업화된 최초의 고분자 발포체는 1920 년 경에 만들어진 고무 스폰지(sponge rubber)였으며, 일반적으로 고분자 물질이 발포 폼으로 만들어질 수 있으나 상업적으로 개발된 것은 소수에 불과하 다. 1937년 독일의 Otto Bayer가 우레탄을 상업적으 로 개발한 이후 2 차 세계대전이 시작되면서 섬유, 도료, 발포제용 우레탄의 개발이 활성화 되었으며 독일의 기술이 미국, 영국으로 넘어가면서 광범위 한 연구가 시작되었다 ${ }^{14,15)}$. 폴리우레탄은 중량에 비 하여 강도가 높고, 각종 구조에 맞는 성형성을 가 지며, 양호한 단열성 등의 장점을 가진다. 또한 액 체 상태에서 수많은 기포를 분산시킨 후 여러 가지 방법으로 이 상태를 안정화 및 고체화시켜서 합성 하게 된다. 분류기준에 따라 여러 가지로 분류 할 수 있으며 물질 속에 수없이 분산되어 있는 기포의 형태에 따라 열린 연속기포(open cell)와 닫힌 독립 기포(closed cell)로 구별되며, 물성에 따라 경질폼 (rigid foam), 연질폼(flexible foam), 반경질폼(semirigid foam)으로 분류된다.

본 연구에 앞서 전보에에서는 그라운드로 쓰이는 PU/ MWNT 필름의 제조시 폴리우레탄 내에서의 MWNT 함유량과 분산시간에 따른 분산성을 가시광선/근적 외선/분광광도계(UV/VIS/NIR Spectrometer)와 비디오 광학현미경(SV-550 Video microscope system)을 이용 하여 평가하고 MWNT 함유량과 분산시간에 따른 $\mathrm{PU} / \mathrm{MWNT}$ 그라운드 필름의 인장특성 및 전자부품 간지로서의 적용가능성 확인을 위해 전기전도성을 측정하고 이에 따른 결과를 고찰함으로서 PU/MWNT 복합발포체의 베이스 필름제조에 관한 기초연구를 수행하였다.

본 연구에서는 다양한 용제에 분산된 탄소나노튜 브 분산액을 발포제를 사용하여 발포 필름의 제조 시 용제와 발포제가 PU/MWNT 발포필름의 발포체
를 형성하는데 미치는 영향을 조사하고 PU/MWNT 발포필름 제조에 필요한 최적 발포체 제조조건을 도출하고자 하였다.

\section{2. 실 험}

2.1 시료

본 연구에서 사용한 원료는 모두 상업적으로 시 판되는 재로로서 MWNT 분산용매, 폴리우레탄, 발 포제, 가교제 그리고 첨가제를 혼합하여 사용하였 다. 탄소나노튜브는 MWNT(한화 나노텍, CM-95 type) 로서 CVD 방법으로 제조한 순도 $95 \%$, 길이 $10 \sim 20$ $\mu \mathrm{m}$, 직경 $10 \sim 15 \mathrm{~nm}$ 의 나노튜브를 사용하였고 Polyurethane 수지는 (주)빅스에서 생산된 고형분 PU V-coat 7089 로서 2 액형의 폴리우레탄, 고형분 $92 \%$ 이며 가교제 는 V-coat IT 131이다. Table 1은 본 연구에 사용된 Polyurethane 수지의 물성을 보여주고 있다. MWNT 분산용매는 $\mathrm{DMF}(\mathrm{N}, \mathrm{N}$-dimethylformamide, (주)한원정 밀화학), IPA(Isopropyl alcohol, (주)덕산약품공업), MEK (Methyl ethyl ketone, (주)덕산약품공업), Toluene((주) 아인케미칼)을 정제없이 사용하여 총 4종의 MWNT 분산액을 제조하였다. Table 2는 사용된 MWNT 분 산용매를 나타내었고, Table 3에 4종의 발포제를 사 용한 발포제의 특성을 나타내었다.

\section{$2.2 \mathrm{PU} / \mathrm{MWNT}$ 발포필름의 제조}

MWNT 분산용매 및 발포제가 최종 발포필름의 발포성에 미치는 영향을 조사하기 위해 Table 2에 보인 IPA(Isopropyl alcohol), DMF(N,N-dimethylformamide), MEK(Methyl ethyl ketone), Toluene 4종의

Table 1. Thy physical properties of polyurethane

\begin{tabular}{lc}
\hline \multicolumn{2}{c}{ Physical properties of PU } \\
\hline Boiling point & $145^{\circ} \mathrm{C}$ \\
Melting point & $<0^{\circ} \mathrm{C}$ \\
Density & $\sim 1.1 \mathrm{~g} / \mathrm{cm}^{3}$ \\
Decomposition temperature & $150^{\circ} \mathrm{C}$ \\
\hline
\end{tabular}

Table 2. Dispersion solvents and content of MWNT

\begin{tabular}{ccc}
\hline Name & Solvent & Content of MWNT(wt\%) \\
\hline D/MWNT & DMF & 3 \\
I/MWNT & IPA & 3 \\
M/MWNT & MEK & 3 \\
T/MWNT & Toluene & 3 \\
\hline
\end{tabular}


Table 3. Blowing agents and its physical properties

\begin{tabular}{cccc}
\hline Name & Type & Decomposition temperature $\left({ }^{\circ} \mathrm{C}\right)$ & Product rate of gas $(\mathrm{ml} / \mathrm{g})$ \\
\hline $\mathrm{A}$ & Organic I & $155-165$ & $120-130$ \\
$\mathrm{~B}$ & Organic II & $158-164$ & $125-140$ \\
$\mathrm{C}$ & Capsule & $75-85$ & - \\
$\mathrm{D}$ & Inorganic & $155-190$ & $115-125$ \\
\hline
\end{tabular}

Table 4. Foaming conditions of PU/MWNT foaming film

\begin{tabular}{|c|c|c|c|c|}
\hline & Dispersion solvent & Blowing agent & Polyurethane & $\begin{array}{c}\text { Manufacturing } \\
\text { condition }\end{array}$ \\
\hline 1 & \multirow{4}{*}{ IPA } & $\mathrm{A}$ & \multirow{16}{*}{$\begin{array}{l}\text { High solid polyurethane } \\
\text { V-coat } 7089\end{array}$} & \multirow{16}{*}{$\begin{array}{l}\text { Thickness : } 500 \mu \mathrm{m} \\
\text { Drying temp.: } 170^{\circ} \mathrm{C} \\
\text { Drying time }: 15 \mathrm{~min}\end{array}$} \\
\hline 2 & & B & & \\
\hline 3 & & $\mathrm{C}$ & & \\
\hline 4 & & $\mathrm{D}$ & & \\
\hline 5 & \multirow{4}{*}{$\mathrm{DMF}$} & A & & \\
\hline 6 & & $\mathrm{~B}$ & & \\
\hline 7 & & $\mathrm{C}$ & & \\
\hline 8 & & $\mathrm{D}$ & & \\
\hline 9 & \multirow{4}{*}{ MEK } & $\mathrm{A}$ & & \\
\hline 10 & & B & & \\
\hline 11 & & $\mathrm{C}$ & & \\
\hline 12 & & $\mathrm{D}$ & & \\
\hline 13 & \multirow{4}{*}{ Toluene } & A & & \\
\hline 14 & & $\mathrm{~B}$ & & \\
\hline 15 & & $\mathrm{C}$ & & \\
\hline 16 & & $\mathrm{D}$ & & \\
\hline
\end{tabular}

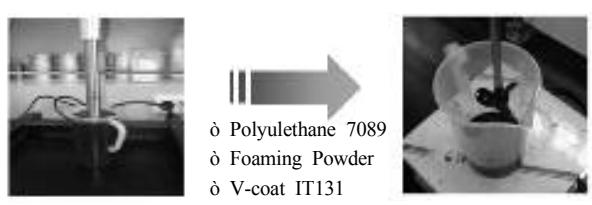

Dispersion solution

Mixture

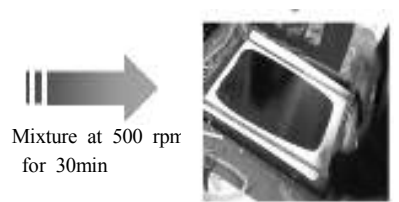

Casting

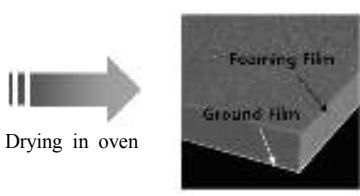

PU/MWNT Foaming

Fig. 1. Production of PU/MWNT foaming film.

용매를 MWNT 분산용매로 사용하였고, Table 3에 보여준 총 4종의 발포제를 사용하여 PU/MWNT 발 포필름 16 가지를 제조하였다. 발포필름의 제조조건 은 Table 4에 나타내었다. 폴리우레탄을 다른 첨가 제와 혼합하기 전에 $80^{\circ} \mathrm{C}$ 에서 24시간 숙성을 시킨 후, MWNT분산용액, 가교제, 발포제를 혼합하여 교 반기의 속도를 $500 \mathrm{rpm}$ 으로 하여 30 분간 교반한 후 이형지 위에서 casting 방법으로 크기는 가로 $20 \mathrm{~cm}$,
세로 $30 \mathrm{~cm}$ 이며, 두께 $500 \mu \mathrm{m}$ 로 제조한 후 용매 제거 를 위해서 건조기(LDO-360F, (주)랩테크) 내에서 건 조온도 $170^{\circ} \mathrm{C}$ 에서 15 분간 건조하여 용매를 제거하 였다. Fig. 1에 발포필름 제조공정의 순서를 보여주 고 있다. 그리고 최적 발포필름 제조조건을 결정하 기 위해 분산용매를 IPA로 하고 발포제를 $\mathrm{A}, \mathrm{B}, \mathrm{C}$ 를 동일하게 $2 \mathrm{part}$ 의 함량을 첨가하여 발포필름을 제조할 때 PU 50part에 IPA 분산용액을 3part와 5part 
2가지로 바꾸어 주고 분산용액의 농도조절과 혼합 을 용이하게 하기위해 첨가물로서 휘발성 용액인 $\mathrm{MEK}^{2}$ 의 함량을 1part와 2part로 그리고 발포온도를 $150^{\circ} \mathrm{C}$ 와 $160^{\circ} \mathrm{C}$, 발포필름 두께를 2 가지 바꾸어 주 면서 24가지의 시료를 제조하였다.

이때 용매 제거를 위해서 건조기 내에서 건조온 도 $150^{\circ} \mathrm{C}$ 와 $160^{\circ} \mathrm{C}$ 에서 5 분간 건조하여 용매를 제 거하였다. 그리고 발포된 필름의 두께를 Digimatic Micrometer(MDC-25PJ, Itutoyo Co.)로 각 5회 측정하 였으며 각 시료와 그들의 평균두께를 Table 5에 나 타내었다.

\section{$2.3 \mathrm{PU} / \mathrm{MWNT}$ 발포필름의 특성 측정}

$\mathrm{PU} / \mathrm{MWNT}$ 발포필름의 표면 특성을 측정하기 위하 여 Video Microscope System(iCamscope-305A, Sometech.
Co. Ltd)을 이용하여 접촉 검사방식으로 $\times 500$ 배율로 발포필름 표면 사진을 촬영하였다. 발포조건이 PU/ MWNT 발포필름의 미세구조에 미치는 영향을 평가 하기 위해 주사전자현미경(Scanning Electron Microscope ; SEM, JEOLS-4200 : HITACHI, Japan)을 사용하였다. 시료를 두께 방향으로 절단한 뒤 백금 코팅을 하여 100 배의 배율로 두께방향 발포의 기포형태를 관찰하 였다. 전기저항성은 전도성 측정기(KEITHLEY 8009, $\mathrm{USA}$ )를 이용하여 측정시간(sec) 15 , 상쇄전압량(Offset Voltage, V) 0, 교체전압(Alternating Voltage, V) 50 , 측 정범위(Current Range, $\mathrm{mA}$ ) 20의 조건하에서 부피저 항성 및 표면 저항성을 측정하였다. 그리고 전기저 항성과 발포필름의 발포상태 그리고 이들의 SEM 사 진 특성과 비교하기 위해 발포필름의 밀도를 측정하 였다.

Table 5. Foaming conditions of PU/MWNT film

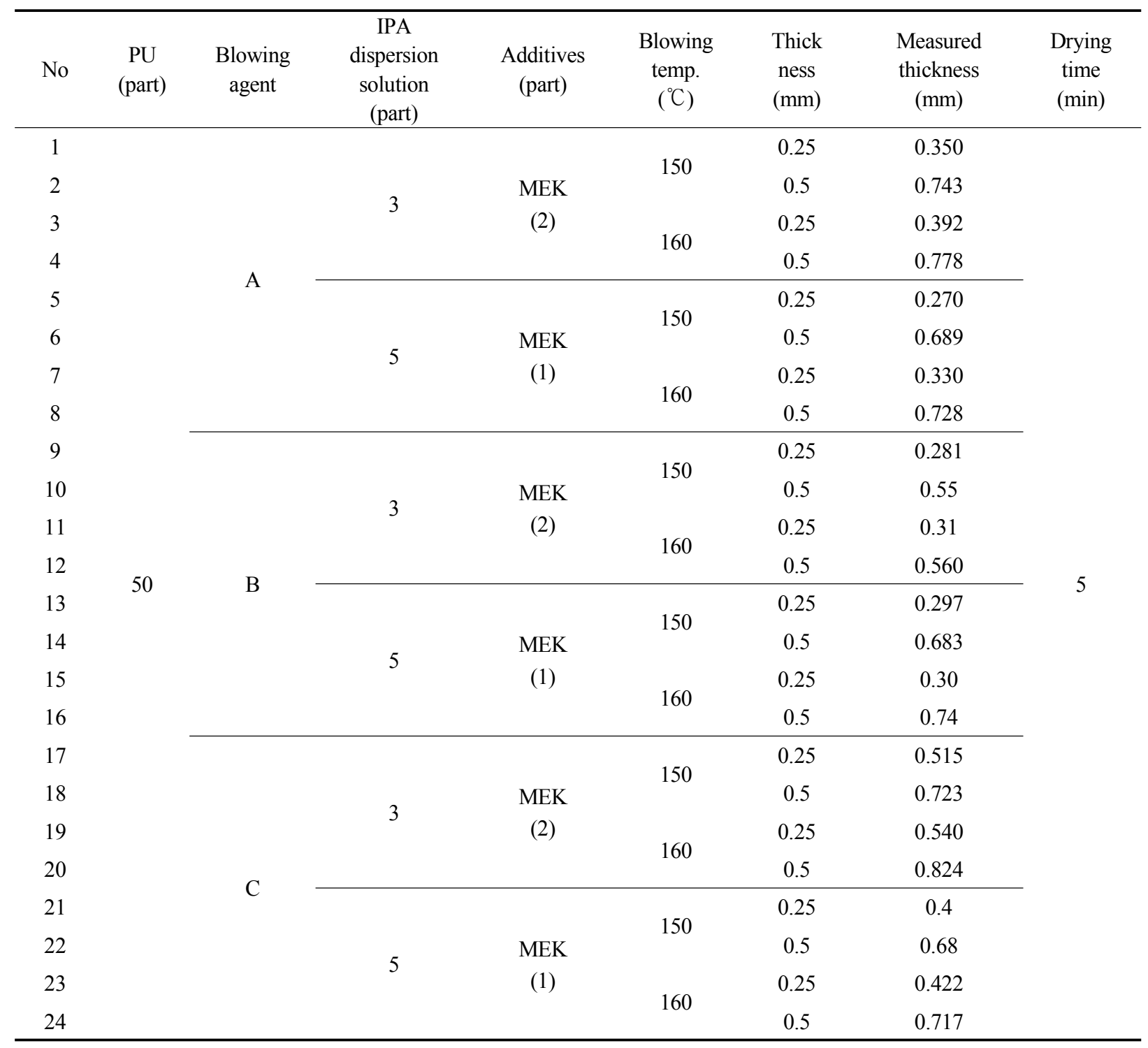


24 개 각 시료 당 5 개를 $2.5 \times 2.5 \mathrm{~cm}$ 로 제작하여 두 께를 10 회 측정하여 이들의 평균 두께(표준편차; $0.008 \sim 0.06 \mathrm{~mm})$ 를 사용하여 부피를 계산하고 이들 의 무게를 측정하여 계산된 부피로 나누어 밀도(표 준편차; $0.004 \sim 0.01 \mathrm{~g} / \mathrm{mm}^{3}$ )를 계산하였다.

\section{3. 결과 및 고찰}

$3.1 \mathrm{MWNT}$ 분산용매와 발포제에 따른 발포필름의 특성 분석

\subsubsection{PU/MWNT 발포필름의 표면특성}

Fig. 2는 분산용매와 발포제에 따른 발포필름의 표면 특성을 나타내었다. IPA 분산용매를 사용하여 제조한 필름의 경우 $\mathrm{A}($ Organic I ), $\mathrm{B}$ (Organic II), $\mathrm{D}$ (Inorganic) 발포제에서는 발포된 셀(cell)이 필름 전체에 고르게 형성이 되었고 각각 셀의 크기가 고 르게 나타났으나 $\mathrm{C}$ 발포제(캡슐형 발포제)에서는 셀의 크기가 일정하지 못하며 필름 표면 전체에 고 르게 형성이 되지 못한 것을 볼 수 있다. $\mathrm{DMF}$ 분 산용매와 발포제 $\mathrm{A}, \mathrm{B}, \mathrm{C}, \mathrm{D}$ 를 사용하여 발포 시킨 필름의 표면은 IPA 분산용매에 비해 전반적으로 cell의 형성이 잘 이루어지지 않음을 볼 수 있다. 이 는 분산용매로 쓰인 $\mathrm{DMF}$ 의 용해도 파라메타(SP치,
Solubility Parameter)가 4종의 용매 중 가장 높은 값 을 가짐으로써 발포가 원활히 이루어지지 않은 것 으로 판단된다. $\mathrm{MEK}$ 와 발포제 $\mathrm{A}, \mathrm{B}, \mathrm{C}, \mathrm{D}$ 를 사용 하여 발포 시킨 경우 $\mathrm{DMF}$ 분산용매에 비해 발포 는 잘 이루어 졌으나 IPA 분산용매로 사용한 경우 에 비해서는 cell의 형태와 분포도가 떨어지는 것을 볼 수 있다. Toluene 분산용매를 사용하여 발포 시 킨 필름의 경우 $\mathrm{D}$ 발포제가 발포도가 다소 떨어지 지만 $\mathrm{A}, \mathrm{B}, \mathrm{C}$ 는 $\mathrm{DMF}, \mathrm{MEK}$ 에 비해 cell이 필름 전 체에 고르게 형성 되었고 개개의 cell 크기도 고르 게 생성된 것을 볼 수 있다. $\mathrm{SP}$ 치가 $\mathrm{DMF}>\mathrm{MEK}>$ Toluene>IPA 순으로 높은 것을 고려하면 용매의 용 해도가 발포 cell 형성에 큰 영향을 미치는 것을 알 수 있다.

\subsubsection{PU/MWNT 발포 필름의 셀 모폴로지}

Fig. 3은 발포시킨 필름의 단면 cell 형상을 나타 내었다. IPA 분산용매를 사용하여 제조한 시료에서 A 발포제(Organic I)는 전체적으로 cell의 형성이 잘 이루어 졌으며 단면 전체에 고르게 퍼져 있는 것을 볼 수 있으며 $\mathrm{B}$ 발포제(Organic II)도 비교적 양호한 발포도를 나타내고 있으며 최종 발포 두께 가 $913 \mu \mathrm{m}$ 로 $180 \%$ 의 발포율을 보였다. 그러나 C 발 포제(Capsule)는 최종 필름의 두께가 $1,583 \mu \mathrm{m}$ 로 $316 \%$

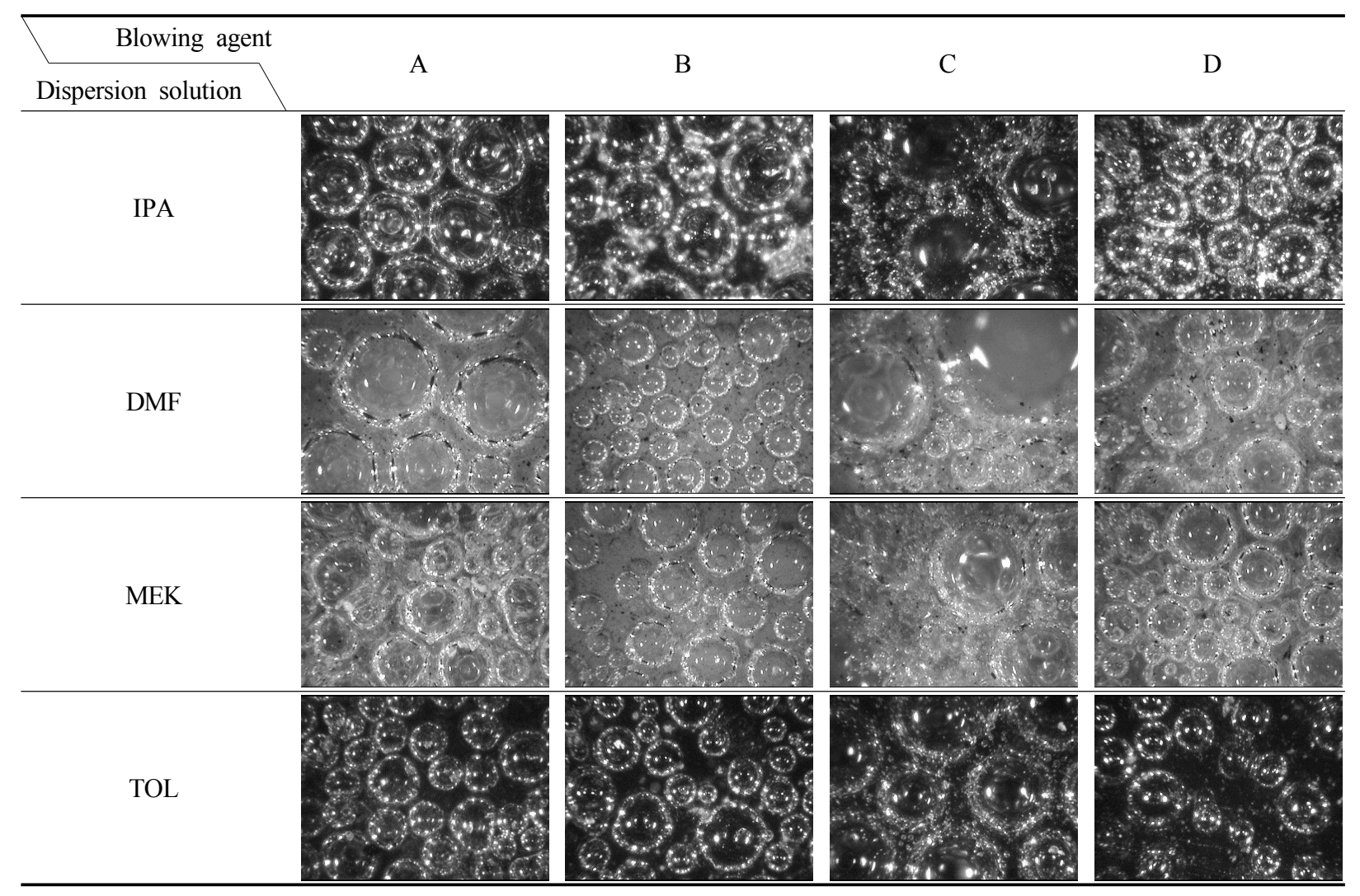

Fig. 2. Surface profile of the PU/MWNT foaming film. 


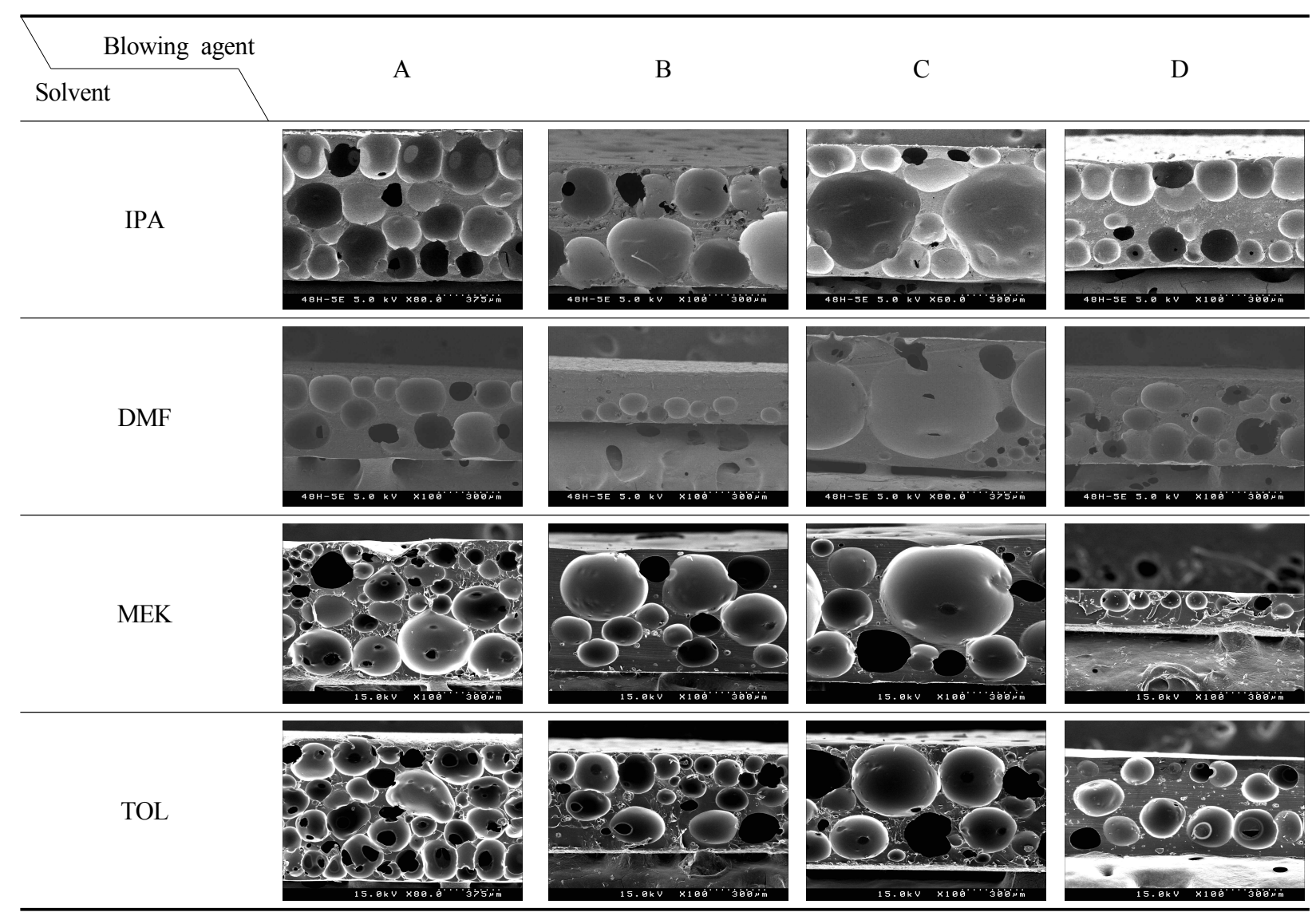

Fig. 3. SEM image of PU/MWNT foam films.

의 발포율을 보여 가장 높은 발포율를 보였으나 단 독 cell의 크기가 필름의 두께 정도로 너무 크게 생 성이 되어 다른 cell이 성장을 못한 것을 볼 수 있 었다. 이러한 현상은 $\mathrm{C}$ 발포제는 발포 온도가 다른 발포제에 비해 낮은 $75-85^{\circ} \mathrm{C}$ 로서 본 제조공정에서 필름의 발포 온도가 $170^{\circ} \mathrm{C}$ 로 과도하게 높기 때문에 발포된 cell의 크기가 급격히 증가 한 것으로 판단 된다. $\mathrm{Kim}$ 등 $^{16)}$ 에 따르면 대형 기포셀은 지속적인 부피 증가를 유발하는 안정적인 반응이 아니라 단 시간에 다량의 기포셀이 발생하는 격렬한 반응에 의해 얻어지며 기포셀 간의 병합과 붕괴가 발생하 기 때문에 발포도를 오히려 감소시킬 수 있으며 제 품 표면으로 거대 기포가 노출되는 경우도 있다고 보고하고 있다. 이러한 결과는 Fig. 2에 보인 필름 의 표면 측정 사진에서도 $\mathrm{C}$ 발포제를 사용한 경우 표면에 cell을 나타내는 것으로 $\mathrm{Kim}$ 등 ${ }^{16)}$ 의 연구 결과와 비슷한 결과를 나타내고 있다.

$\mathrm{B}$ 발포제의 경우 최종 발포필름의 두께가 $523 \mu \mathrm{m}$ 로 캐스팅하여 제조두께를 거의 유지하였고, D 발 포제(Inorganic)는 발포가 다른 발포제에 비해 적게 이루어 진 것을 볼 수 있으며 필름 중심부는 cell 형 성이 거의 되지 않았으나 벽면의 외부는 cell이 형성
된 것을 볼 수 있다. 이는 폴리우레탄 성형의 특징 적인 현상으로서 인테그럴스킨(Integral skin)의 형성 을 들 수 있는데, 이는 반응체 내부의 고온에 의해 발생된 기포가 상대적으로 온도가 낮은 용기 벽면 에서 응축되어 내부에 비해 치밀한 조직이 형성되 는 현상으로 설명될 수 있다 ${ }^{17)}$. 그리고 $\mathrm{DMF}$ 분산 용매에 4종의 발포제를 사용하여 발포시킨 필름의 단면 cell 형상은 다른 분산용매에 비해 $\mathrm{DMF}$ 의 용 해도가 높은 이유로 발포가 잘 이루어지지 않았다. B 발포제는 Fig. 2에 보인 표면 측정에서도 cell의 크기가 미세하게 나타났고, 단면 셀 모폴로지에서 도 cell의 크기가 아주 미세하게 나타난 것을 볼 수 있다. C 발포제는 IPA 분산용매에서와 마찬가지로 거대 cell이 형성이 되어 고르지 못한 발포가 이루 어 진 것을 볼 수 있었다. 최종 발포 두께는 $\mathrm{A}$ 발 포제의 경우 $575 \mu \mathrm{m}, \mathrm{B}$ 발포제 경우 $324 \mu \mathrm{m}, \mathrm{C}$ 발포 제 경우 $677 \mu \mathrm{m}, \mathrm{D}$ 발포제일 경우 $534 \mu \mathrm{m}$ 로 건조시 용매의 휘발로 인한 필름의 두께가 얇아짐을 감안 하지 않는다면 약 $-30 \% \sim 140 \%$ 정도의 발포가 이 루어 진 것으로 보여진다. 한편 $\mathrm{MEK}$ 분산용매에 4 종의 발포제를 사용하여 발포시킨 필름의 단면 cell 형상을 보았을 때 $\mathrm{A}, \mathrm{B}, \mathrm{C}$ 발포제에서는 발포가 
이루어 졌으나 $\mathrm{D}$ 발포제의 경우 발포가 거의 이루 어지지 않음을 볼 수 있다. A 발포제를 사용하여 발포 시킨 필름의 최종 두께는 $840 \mu \mathrm{m}, \mathrm{B}$ 발포제는 $543 \mu \mathrm{m}, \mathrm{C}$ 발포제는 $524 \mu \mathrm{m}, \mathrm{D}$ 발포제는 $345 \mu \mathrm{m}$ 로 발 포가 이루어 졌다. 마지막으로 Toluene 분산용매에 4종의 발포제를 사용하여 발포시킨 필름의 단면 cell 형상은 $\mathrm{A}$ 와 $\mathrm{B}$ 발포제의 경우 비교적 cell의 크 기가 고르게 형성되었지만 cell의 파열이 보이는 부 분이 있었다. C 발포제의 경우 다른 3 종류의 용매, 즉 IPA, DMF, MEK 분산용매를 사용한 발포필름 에 비해 우수한 발포성을 보이고 있고, D 발포제의 경우 다른 발포제에 비해 발포가 충분히 이루어지 지 않음을 볼 수 있었다. 발포제에 따른 최종 발포 필름의 두께는 $\mathrm{A}$ 발포제일 경우 $754 \mu \mathrm{m}, \mathrm{B}$ 발포제 는 494 $\mu \mathrm{m}, \mathrm{C}$ 발포제는 $645 \mu \mathrm{m}, \mathrm{D}$ 발포제는 $540 \mu \mathrm{m}$ 로 약 $-2 \% \sim 150 \%$ 정도의 발포도를 보이고 있다. 따 라서 MWNT가 IPA와 Toluene에 분산된 용액을 사용하여 polyurethane을 발포 시켰을 때 4종류의 발포제에서 발포가 이루어짐을 볼 수 있었으나, 분 산용액이 $\mathrm{DMF}$ 인 필름에서는 발포가 잘 이루어지 지 않음을 볼 수 있었다. 이는 발포제가 cell을 형 성할 때 첨가된 용매에 의해 직접적인 영향을 받은 것이라 볼 수 있다. 또한 $\mathrm{D}$ 발포제는 대부분의 분 산용매에서 발포가 잘 이루어지지 않음을 확인 할 수 있었다.

\subsection{3 전기저항도}

Fig. 4는 PU/MWNT 발포 필름의 부피 전기저항 도를 나타내었다. PU/MWNT 발포필름의 전기저항 도는 $10^{13} \sim 10^{15} \Omega \cdot \mathrm{cm}$ 을 나타내고 있으며, 각각의 필 름의 용매와 발포제에 따라 전기저항도는 전 분산용 매에서 A 발포제(Organic I)와 D 발포제(Inorganic)
가 가장 낮은 전기저항도를 나타내고 있는 것을 볼 수 있다. 또한 전체적으로 분산용매가 IPA와 Toluene 으로 발포시킨 필름이 $\mathrm{DMF}$ 와 $\mathrm{MEK}$ 를 사용하여 발 포시킨 필름 보다 전기저항도가 낮은 값을 보임을 알 수 있었다. 그러나 D 발포제는 다른 시료에 비 해 발포가 잘 이루어지지 않아 최종 필름의 두께가 다른 시료에 비해 얇아 부피 전기저항도가 낮은 값 을 가지는 것으로 사료된다.

\section{2 발포조건에 따른 발포필름의 특성 분석}

\subsection{1 셀 모폴로지}

Fig. 5(a)는 IPA/MWNT 분산용매와 A 발포제(Organic I)를 사용하여 발포시킨 필름의 단면 cell 모폴로 지를 나타내었다. 건조온도 $150^{\circ} \mathrm{C}$ 에서는 전체적으 로 cell의 크기가 고르게 형성되었으며 필름 단면을 보았을 때 전반적으로 발포가 고르게 이루어 졌다. 필름 제조두께 $0.25 \mathrm{~mm}$ 에서는 두께가 얇아 cell이 단 면에 한층으로 이루어 진 것을 볼 수 있었으며, 제 조두께 $0.5 \mathrm{~mm}, \mathrm{IPA}$ 분산액 함량 $5 \mathrm{part}$ 에서 발포형상 이 가장 좋은 것으로 판단된다. $160^{\circ} \mathrm{C}$ 에서 건조시 킨 필름의 단면 cell은 건조온도 $150^{\circ} \mathrm{C}$ 에 비해 단면 내에 cell의 수가 많이 생성된 것을 볼 수 있었고 제조두께는 $0.25 \mathrm{~mm}$ 보다 $0.5 \mathrm{~mm}$ 에서 더욱 발포가 잘 이루어 진 것을 볼 수 있으며 이는 Fig. 6 에서 볼 수 있듯이 foam 밀도가 동일 조건하에서 $150^{\circ} \mathrm{C}$ 보다 16 $0^{\circ} \mathrm{C}$ 에서, $0.25 \mathrm{~mm}$ 보다 $0.5 \mathrm{~mm}$ 에서 낮은 값을 가짐으로서 발포가 잘 이루어질수록 필름 내 cell의 생성이 증가 하여 밀도가 감소하는 것으로 확인되었다.

Fig. 5(b)는 IPA/MWNT 분산용매와 B 발포제(Organic II)를 사용하여 발포시킨 필름의 단면 cell 모폴로 지를 나타내었다. $150^{\circ} \mathrm{C}$ 에서 건조시킨 필름은 cell의

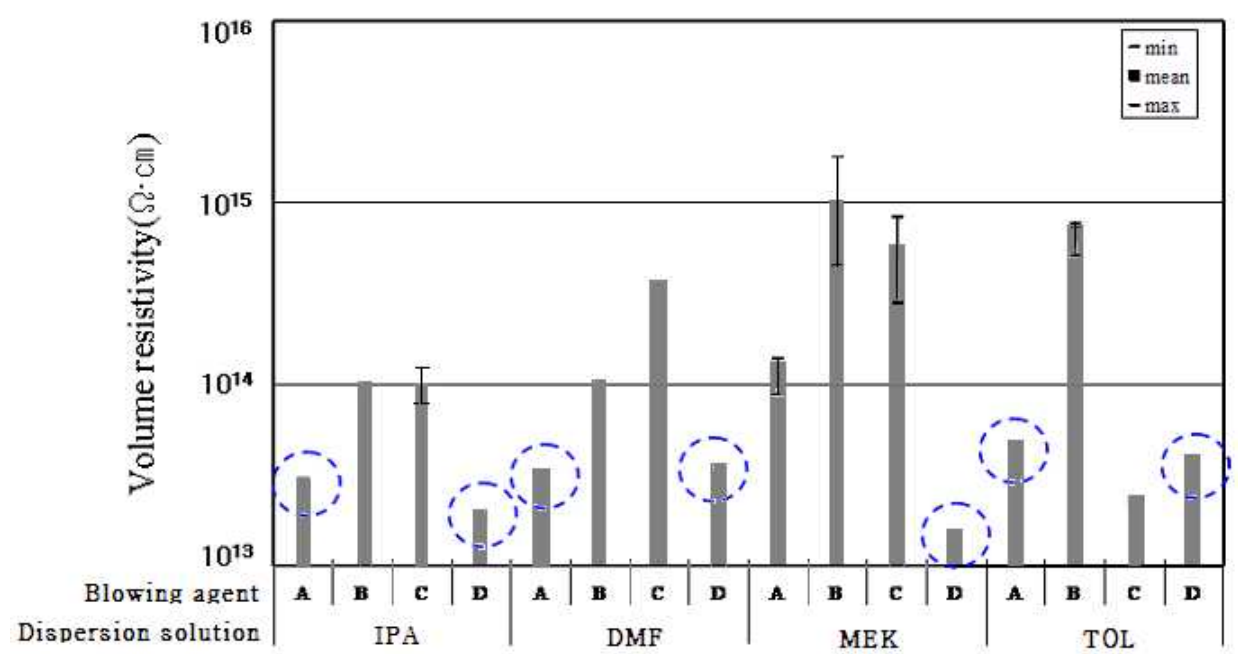

Fig. 4. Volume resistivity of PU/MWNT foaming film. 


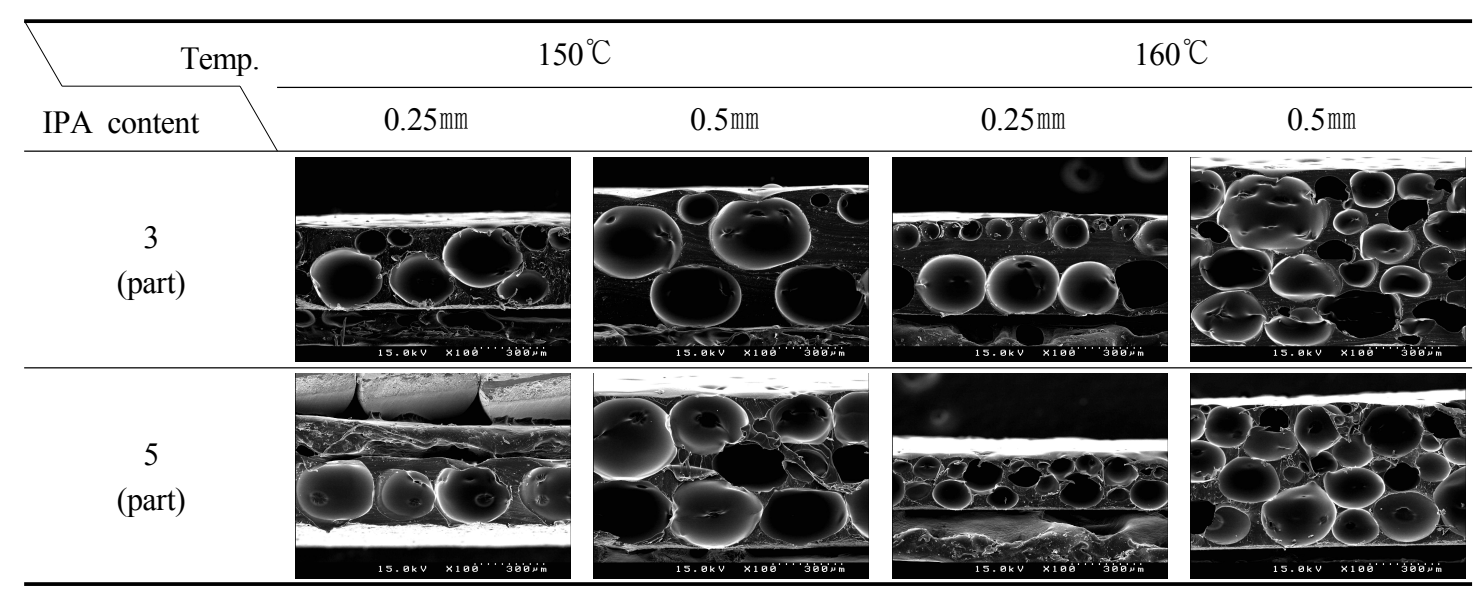

(a) A blowing agent

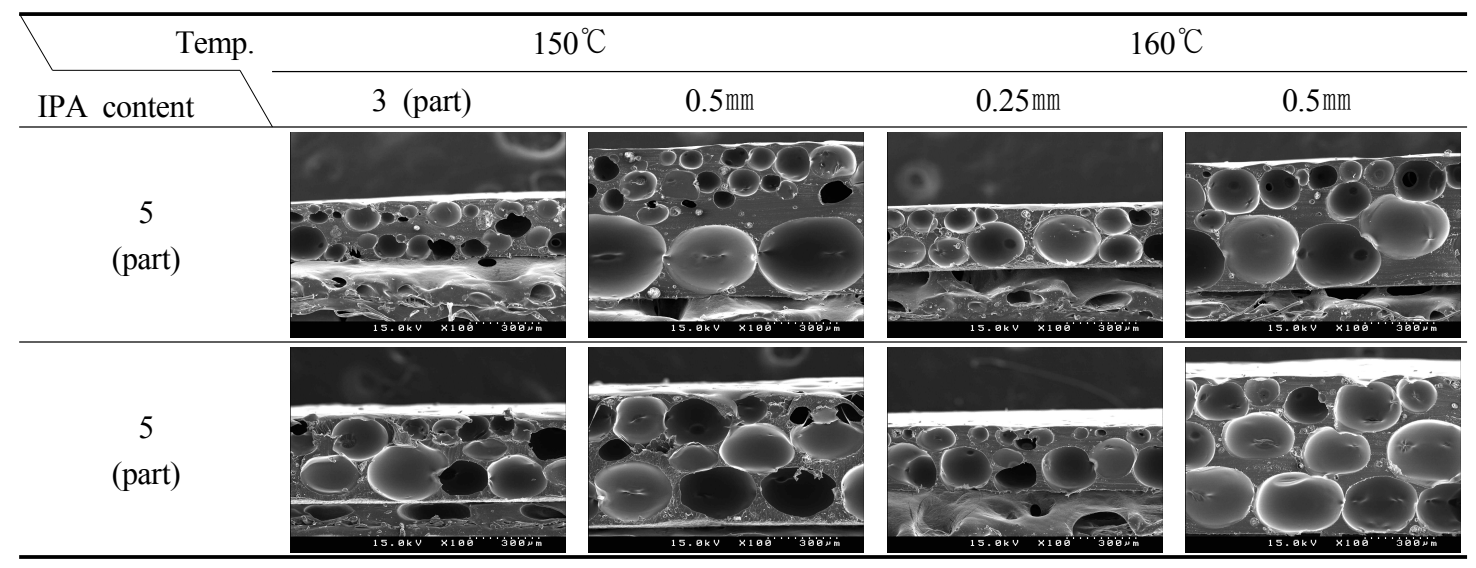

(b) B blowing agent

IPA content

(c) $\mathrm{C}$ blowing agent

Fig. 5. SEM of the PU/MWNT foaming film.

형성이 이루어지기는 하였지만, 분산용액 3part 함 량에서는 cell이 성장을 하지 못하여 기포의 크기가 작은 것이 많이 관찰되어 foam 밀도가 가장 높은 값 을 나타내었다. 이러한 현상은 B 발포제(Organic II) 는 적정 발포온도가 $158-164^{\circ} \mathrm{C}$ 이나 필름건조온도가 $150^{\circ} \mathrm{C}$ 로 온도가 낮았고 또한 건조시간이 짧아서 cell 의 성장이 적게 이루어 진 것으로 사료된다.
Lee 등 ${ }^{18)}$ 에 따르면 발포온도는 발포시간과 더불어 cell의 성장에 직접적인 영향을 미치고, 발포시간은 cell의 성장을 조절하여 최종 발포체의 cell 크기를 결정하는 주된 요인이 된다고 하였다. $160^{\circ} \mathrm{C}$ 에서 건조시킨 필름의 단면 cell 모폴로지는 $150^{\circ} \mathrm{C}$ 보다 cell이 더 많이 형성되고 성장이 잘 이루어 졌으며 제조두께 $0.5 \mathrm{~mm}$ 에서 발포가 양호하게 이루어 진 것을 
볼 수 있었으며 이 또한 Fig. 6 의 foam 밀도가 $160^{\circ} \mathrm{C}$, $0.5 \mathrm{~mm}$ 에서 낮은 값을 가짐으로서 발포성을 확인 할 수 있다.

Fig. 5(c)는 IPA/MWNT 분산용매와 C 발포제(Capsule) 를 사용한 필름의 단면 cell 모폴로지를 나타내었다.

Table 4의 실험에서는 발포온도가 $170^{\circ} \mathrm{C}$ 로서 과 도한 온도로 인해 거대 cell이 형성이 되었으나 Fig. 5 (c)에서 볼 수 있듯이 온도를 $150^{\circ} \mathrm{C}$ 로 낮추어서 필름을 제작을 하였을 때 거대 cell이 형성이 되지 않고 각각의 cell 크기가 고르게 형성이 된 것을 볼 수 있었다. 개개의 cell이 다른 발포제 즉, $\mathrm{A}$ 와 $\mathrm{B}$ 발 포제로 형성된 cell 보다 크기가 컸으며 이로 인해 최종 발포 두께도 다른 필름에 비해 두껍게 형성이 되었는데 이는 Fig. 6의 foam 밀도가 A와 B발포제 보다 $\mathrm{C}$ 발포제를 사용한 필름의 값이 $0.01-0.02 \mathrm{~g} / \mathrm{mm}^{3}$ 정도 낮은 값을 가짐으로서 확인할 수 있다. 또한 Fig. 5(c)에서 $160^{\circ} \mathrm{C}$ 에서 건조시킨 필름의 단면 cell 모폴로지를 보았을 때, Table 4의 실험에서 보인 독립된 거대 cell이 보이지 않는 이유는 $10^{\circ} \mathrm{C}$ 가량 온도가 낮은 이유도 있지만 건조 시간이 5 분으로 이전의 15 분에서 10 분 단축이 되어 cell이 형성된 후 성장 시간을 줄였기 때문에 거대 cell이 생성이 되지 않은 것으로 사료된다.

\section{2 .2 전기저항도}

1) 표면 전기저항

Fig. 7은 PU/MWNT 발포 필름의 표면 전기저항 결과를 나타내었다. Neat PU필름 시료의 표면 전기 저항 값 $10^{18} \Omega / \mathrm{sq}$ 정도보다 $\mathrm{PU} / \mathrm{MWNT}$ 발포 필름 시 료의 표면 전기저항 값이 대부분 낮은 분포를 보이
며 특히 $6,8,24$ 번 시료의 경우 $10^{14} \Omega / \mathrm{sq}$ 정도로서 낮은 표면 전기저항 값을 가지는 것을 볼 수 있으 며 모든 시료에서 $0.25 \mathrm{~mm}$ 로 제조한 필름 보다 $0.5 \mathrm{~mm}$ 로 제조한 필름의 표면 전기저항 값이 낮게 나온 것을 볼 수 있다. 이는 $0.5 \mathrm{~mm}$ 로 제조한 필름의 경우 $0.25 \mathrm{~mm}$ 로 제조한 필름보다 동일한 표면적에서 $\mathrm{MWNT}$ 분산용액의 절대량이 크기 때문에 MWNT가 더 많 이 함유되어 있으며, 또한 $0.25 \mathrm{~mm}$ 로 제조한 필름보 다 발포가 잘 이루어져 필름내부에서 발포가 이루 어지면서 MWNT가 표면으로 밀집이 되어 이러한 현상이 나타난 것으로 생각된다.

\section{2) 부피 전기저항}

Fig. 8은 PU/MWNT 발포 필름의 부피 전기저항 결과를 나타내었다.

Neat PU필름시료의 부피 전기저항 값 $10^{16} \Omega \cdot \mathrm{cm}$ 보다 PU/MWNT 발포 필름의 부피 전기저항 값이 대부분 낮은 분포를 보이며 $5,6,8$ 번 시료가 다른 시료에 비해 낮은 부피 전기저항을 가지며 그 중 6 번 시료가 가장 낮은 부피 전기저항 값을 보였다. 그리고 이들 시료의 부피 저항치는 Fig. 7에서 보 인 표면 저항치와 같은 경향성을 보이며 단지 24번 시료 $\left(160^{\circ} \mathrm{C}, 0.5 \mathrm{~mm}, \mathrm{MWNT}\right.$ 분산액 5 part, Capsule발 포제)의 경우만 다른 경향성을 보이는 것은 특이한 결과로 사료된다. 특히 6,8 번 시료는 표면 전기저 항 값과 부피 전기저항 값이 전 시료 중에서 가장 낮은 값들을 가졌고 전도성이 가장 우수한 것으로 나타났다. 이들 시료가 발포성도 우수한 시료들임을 감안하면 cell의 형상이 깨끗하게 원형을 유지하고 필 름에 전체적으로 고르게 분포되어 있는 시료가 cell의

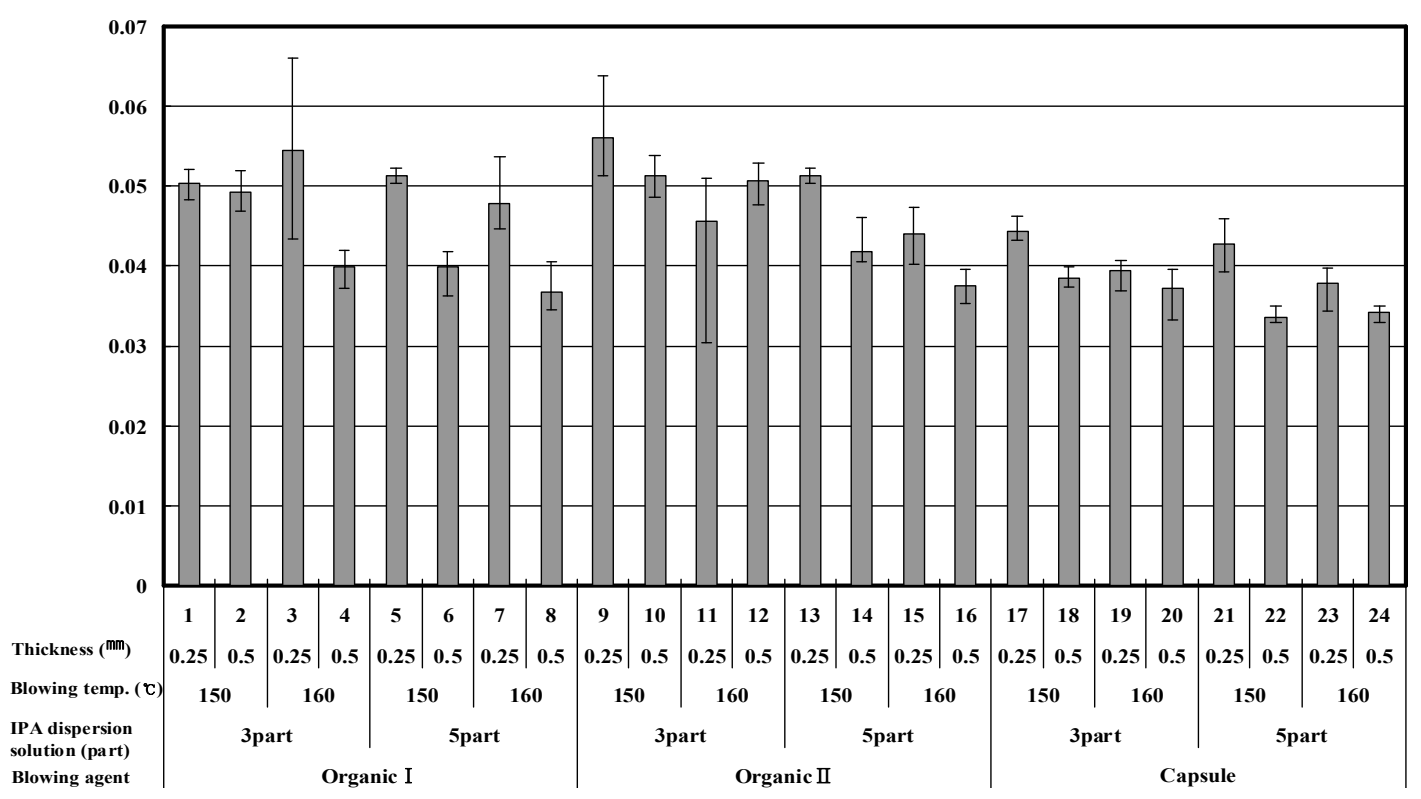

Fig. 6. Foam density of PU/MWNT foaming film. 


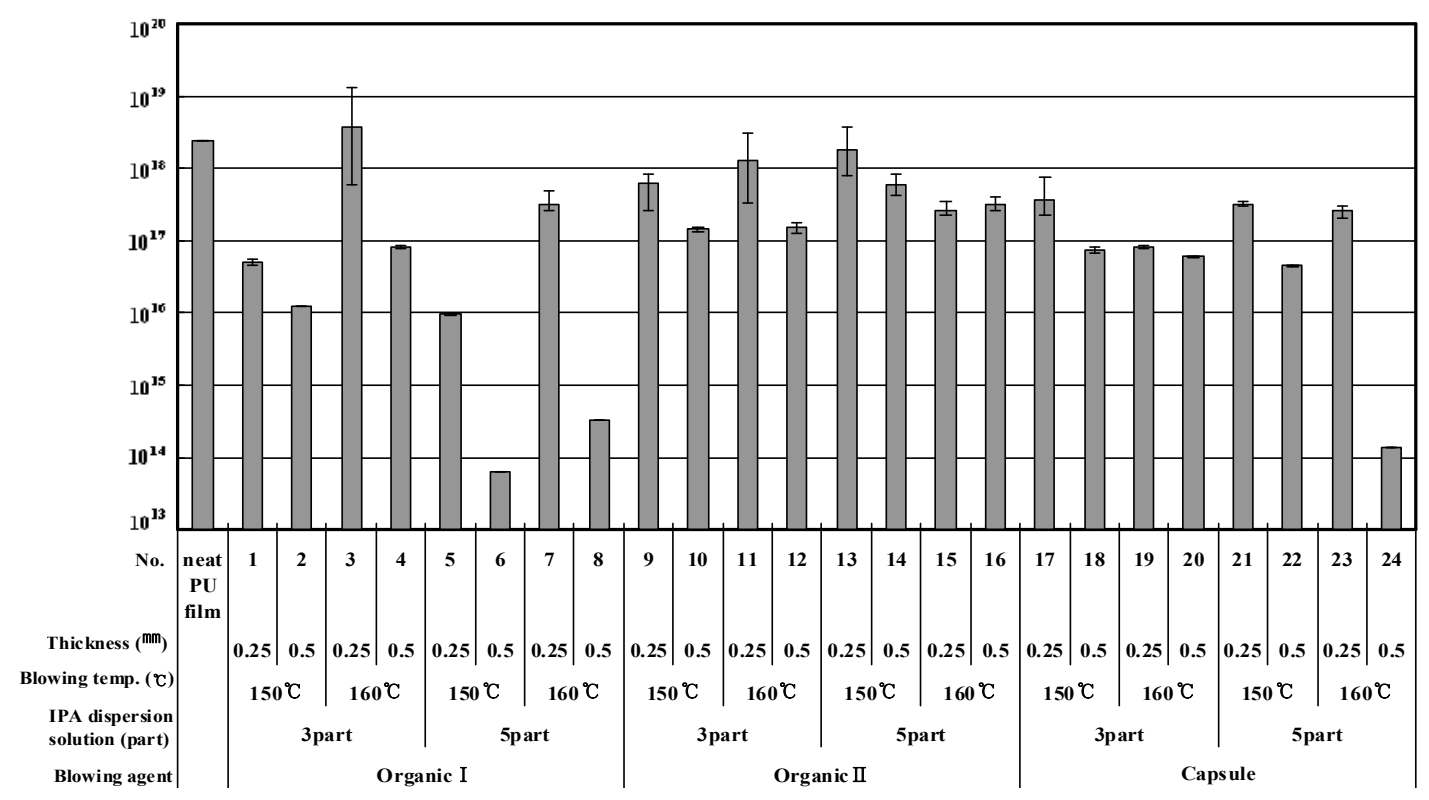

Fig. 7. Surface resistivity of PU/MWNT foaming film.

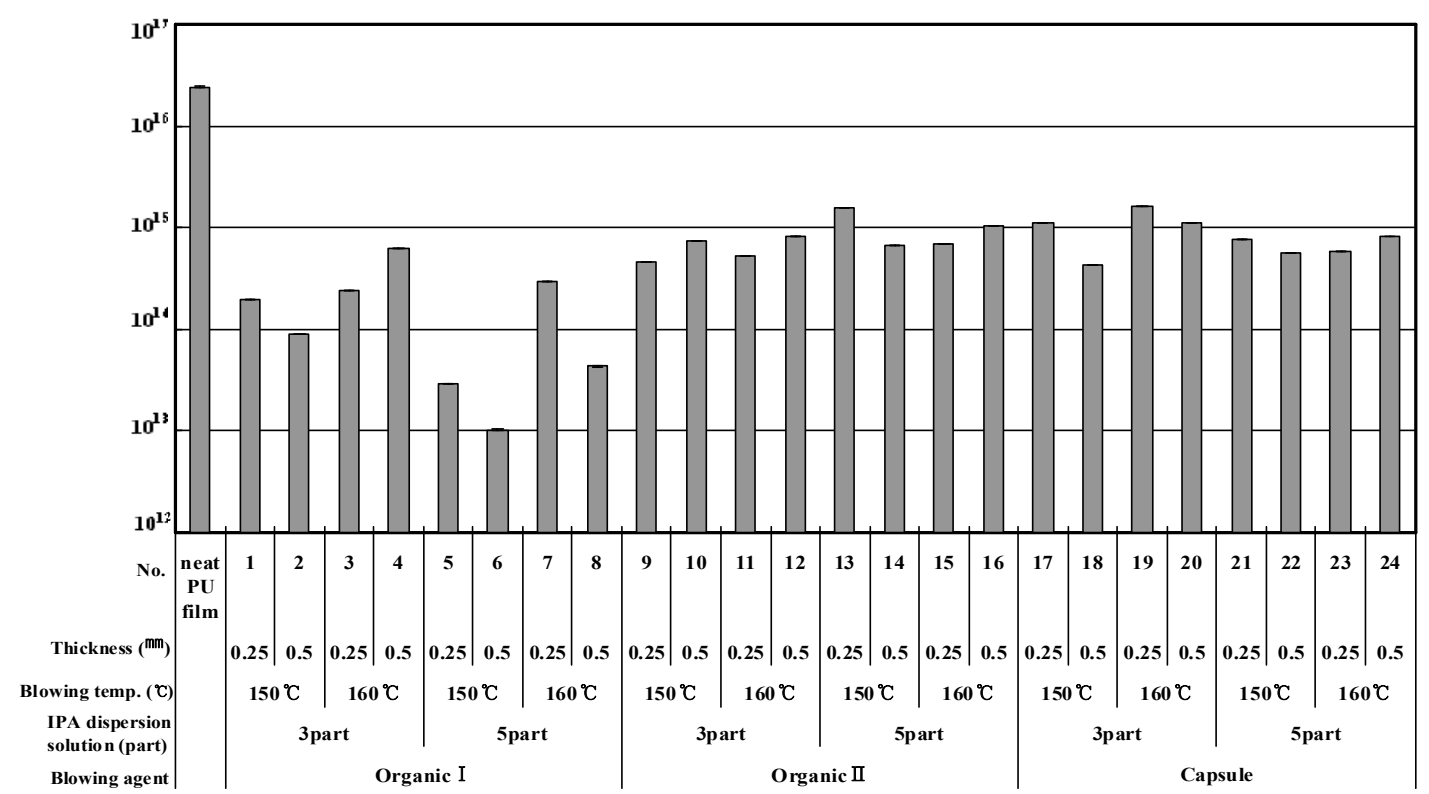

Fig. 8. Volume resistivity of PU/MWNT foaming film.

형상이 찟어지거나 발포가 잘 이루어지지 않은 시료 보다 전기저항이 낮은 값을 보임을 알 수 있다.

\subsection{3 마찰 대전압}

Fig. 9에 PU/MWNT 발포필름의 마찰 대전압 실 험 결과를 나타내었다.

마찰대전압 측정결과 유기발포제 I, IPA/MWNT 분산용액 $5 \mathrm{part}$ 를 사용한 시료가 다른 제조조건으 로 제작된 시료보다 낮은 마찰 대전압을 가졌으며 6 번 시료는 가장 낮은 마찰 대전압을 보였다.

또한 다른 시료에서는 반감기가 나타나지 않았으 나 $5,6,8$ 번 시료에서는 반감기가 나타났으며, 5 번
시료는 21.00 초, 6 번 시료는 2.20 초, 8 번 시료는 9.00 초로 측정되었다. 6 번 시료가 마찰대전압과 전기저 항값 모두 가장 낮은 값을 가짐으로서 전기적 특 성이 가장 우수한 것으로 나타났다.

마찰 대전압과 반감기는 표면 마찰된 정전기와 대전된 정전기의 감쇄현상으로 Fig. 7의 표면 전기 저항의 결과치와 Fig. 8의 부피전기저항의 결과가 복합되어 나타났으며, 필름 제조 두께가 두껍고 발 포 cell의 형상이 깨끗하며 고르게 이루어 진 필름 이 마찰 대전압이 낮으며 반감기가 짧게 나타나는 것으로 사료된다. 


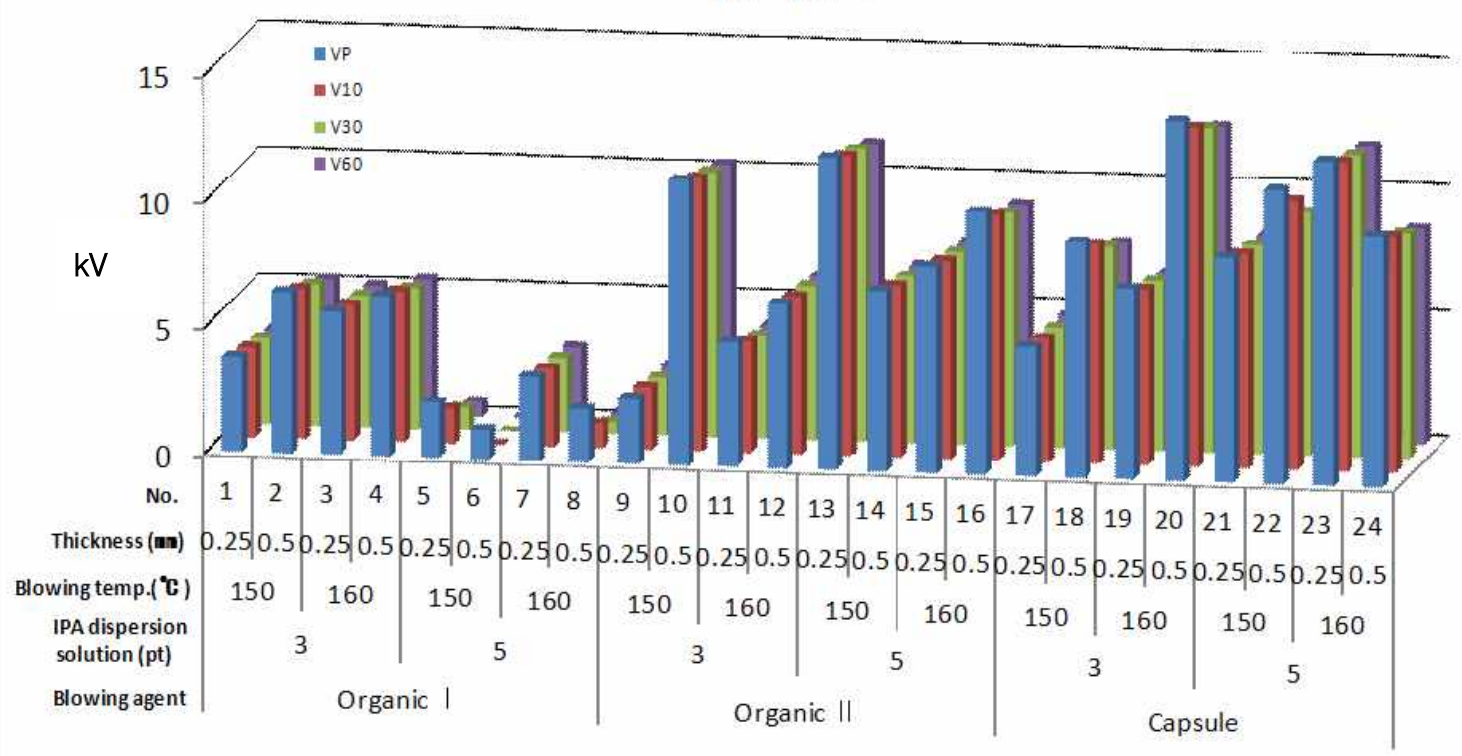

FIg. 9. Triboelectricity of PU/MWNT foaming film.

\section{4. 결 론}

정전기 방지 및 보호용 필림을 제조하기 위해 폴 리우레탄과 MWNT 그리고 발포제를 사용하여 PU/ MWNT 발포필름을 제조하였다. 제조된 필름의 최 적 제조조건을 도출하기 위하여 분산용매와 발포제 종류, 발포온도, 제조두께 등의 발포조건에 따른 PU/MWNT 발포필름의 셀 모폴로지, 전기적 특성을 비교·분석한 결과는 다음과 같다.

1. 유기발포제 I, IPA/MWNT 분산용액 함량 5part, 제조두께 $0.5 \mathrm{~mm}$ 에서 발포된 cello이 가장 균일하고 고르게 형성된 것을 확인하였고, 발포온도 $150^{\circ} \mathrm{C}$ 보다 $160^{\circ} \mathrm{C}$ 에서 cell이 더 많이 형성되었다. 캡슐 발포제의 경우 셀 모폴로지를 비교한 결과 온도 가 $170^{\circ} \mathrm{C}$ 에서 $150^{\circ} \mathrm{C}$ 로 감소 시켜 발포 시켰을 때 거대 cell이 형성이 되지 않음을 볼 수 있었고 이 는 발포온도가 cell의 형성에 직접적인 영향을 미 치는 것으로 확인 할 수 있었다.

2. 표면 및 부피 전기저항도를 측정한 결과 유기발 포제 I, 발포온도 $150^{\circ} \mathrm{C}$, 발포두께 $0.5 \mathrm{~mm}$ 에서 가 장 낮은 전기저항값이 측정되었다.

3. 표면 전기저항도를 측정한 결과 필름 제조 두께 가 $0.25 \mathrm{~mm}$ 에서 $0.5 \mathrm{~mm}$ 로 증가함에 따라 저항값이 감소하는 경향을 보였다.

4. 마찰대전압 측정결과 유기발포제 I, IPA/MWNT 분산용액 5 part를 사용한 시료가 가장 낮은 마찰 대전압을 보였다.

5. 유기발포제 I, IPA/MWNT 분산용액 5 part, 건조 온도 $150^{\circ} \mathrm{C}$ 의 조건에서 제조된 PU/MWNT 발포 필름의 반감기가 2.20 초로 가장 짧은 값을 가짐
을 보였으며, 전기저항값이 낮은 시료가 낮은 마 찰 대전압을 가지며 반감기 역시 짧게 나타났다.

$$
\text { 감사의 글 }
$$

본 연구는 교육과학기술부와 한국연구재단의 지 역혁신인력양성사업으로 수행된 연구결과로 관계 기관에 감사드린다.

\section{참고문헌}

1. N. C. Das, D. Khastgir, and T. K. Chaki, Electromagnetic Interference Shielding Effectiveness of Carbon Black and Carbon Fiber Filled EVA and NR Based Composites, Composites Part A, 31, 10691081(2000).

2. J. H. Park, J. H. Kim, and S. J. Kim, Manufacturing and Characteristics Analysis of PU/MWNT Composite Film for Foaming, Textile Coloration and Finishing(J. of Korean Soc. Dyers \& Finishers), 22(4), 362-372(2010).

3. K. S. Park, S. J. Kim, J. H. Kim, J. H. Park, and O. K. Kwon, Modification of Carbon Nanotube for the Improvement of Dispersion and the Dispersion Characteristics of Carbon Nanotube in Polyurethane, Textile Coloration and Finishing(J. of Korean Soc. Dyers \& Finishers), 22(1), 43-50(2010).

4. A. Chatterjee and B. L. Deopura, Carbon Nanotubes and Nanofibre: An Overview, Fibers and Polymers, 3(4), 134-139(2002).

5. L. S. Schadler, S. C. Giannaris, and P. M. Ajayan, 
Load Transfer in Carbon Nanotube Epoxy Composites, Applied Physics Letters, 73, 3842-3844(1998).

6. Z. Jin, K. P. Pramoda, S. H. Goh, and G. Xu, Poly(vinylidene fluoride)- Assisted Melt-blending of Multi-Walled Carbon Nanotube/Poly(methylmethacrylate) Composites, Materials Research Bulletin, 37, 271-278(2002).

7. D. $\mathrm{Xu}$ and $\mathrm{Z}$. Wang, Role of Multi-Wall Carbon Nanotube Network in Composites to Crystallization of Isotactic Polypropylene Matrix, Polymer, 49, 330-338(2008).

8. K. Jurewicz, S. Delpeux, V. Bertagna, F. Béeguin, and E. Frackowiak, Sopercapacitors from Nanotubes/ Polypyrrole Composites, Chemical Physics Letters, 347, 36-40(2001).

9. N. G. Sahoo, Y. C. Jung, H. J. Yoo, and J. W. Cho, Influence of Carbon Nanotubes and Polypyrrole on the Thermal, Mechanical and Electroactive ShapeMemory Properties of Polyurethane Nanocomposites, Composite Science and Technology, 67, 1920-1929 (2007)

10. E. Kymakis, I. Alexandou, and G. A. J. Amaratunga, Single-Walled Carbon Nanotube- Polymer Composites: Electrical, Optical and Structural Investigation, Synthetic Metals, 127, 59-62(2002).

11. A. Ilcham, A. Srisurichan, A. Soottitantawat, and T. Charinpanitkul, Dispersion of Multi-Walled Carbon Nanotubes in Poly(p-phenylene) Thin Films and
Their Electrical Characteristics, Particuology, 7, 403-407(2009).

12. Y. M. Tsai, T. L. Yu, and Y. H. Tseng, Physical Properties of Crosslinked Polyurethane, Polymer International, 47, 445-450(1998).

13. S. Y. Lee, Y. C. Jung, J. W. Cho, and B. C. Chun, Synthesis and Characteristics of Carbon Nanotube Nanocomposites Crosslinked with Polyurethane, Textile Science and Engineering(J. Korean Fiber Society), 45(4), 247-253(2008).

14. G. Oertel, "Polyurethane Handbook, chap. 2", Hanser Publisher, New York, 1993.

15. D. Klempner and K. C. Frisch, "Handbook of Polymeric foams and Foam Technology", Oxford University Press, New York, 1991.

16. H. S. Kim and J. W. Youn, A Study on Foaming Characteristics of Polyurethane Depending On Environmental Temperature and Blowing Agent Content, Transactions of Materials Processing, 18, 3(2009).

17. K. H. Lee, R. P. Iliev, and C. B. Park, "Processing Strategies for Rotational Molding of Itergral Skin Polyethylene Foams", ANTEC2004, pp.850-854, 2004.

18. E. J. Lee, D. S. Yoon, K. Y. Sung, M. S. Bang, and J. K. Choi, Preparation of Flame Retardant Foam Using Polyethylene Foam Scrap, J. Korea Society of Waste Management, 26(7), 602-610(2009). 